\title{
Histochemistry and Cell Biology: 61 years and not tired at all
}

\author{
Douglas J. Taatjes ${ }^{1}$. Michael Schrader ${ }^{2} \cdot$ Takehiko Koji $^{3}$. Jürgen Roth ${ }^{4}$
}

Published online: 24 June 2019

c) Springer-Verlag GmbH Germany, part of Springer Nature 2019

Isaac Newton is credited with quipping, "If I have seen further it is by standing on the shoulders of Giants". This remark, made more than 300 years ago is still relevant for today's scientists. Certainly, in our field of Histochemistry and Cell Biology, many of the insights we enjoy and techniques we apply in our research are the result of contributions to the literature provided by our scientific forebearers. As Editors of Histochemistry and Cell Biology, we are entrusted with maintaining the high quality and continued success of the journal instituted by its founders $M$. Chèvremont, Liège; H.W. Deane, New York; P.B. Diezel, F. Duspiva and H. Reznik, Heidelberg; O. Eränkö, Helsinki; P. Gedigk and N. Schümmelfelder, Bonn; W. Gössner, Tübingen; W. Graumann, Göttingen; A. G. E. Pearse, London; W. Sandritter, Frankfurt/Main; T.H. Schiebler, Kiel; G. Siebert, Mainz; and M. Wolman, Tel-Hashomer. The list of the international editors represented a virtual list of "Who's Who" in histochemistry at that time.

\section{Brief history of the journal}

The journal has a long and distinguished history in publishing cutting edge research, technical developments, and special topic issues. A perusal of the contents of the early volumes of the journal reveals a cornucopia of developments of the histochemical methods still widely in use today, contributed by eminent scientists such as P. van

Douglas J. Taatjes

douglas.taatjes@med.uvm.edu

1 Department of Pathology and Laboratory Medicine, Larner College of Medicine, University of Vermont, Burlington, VT 05405, USA

2 College of Life and Environmental Sciences, Biosciences, University of Exeter, Exeter EX4 4QD, UK

3 Department of Histology and Cell Biology, Nagasaki University Graduate School of Biomedical Sciences, Nagasaki 852-8523, Japan

4 University of Zurich, 8091 Zurich, Switzerland
Duijn, Leiden; O. Eränkö, Helsinki; P. Gedigk, Bonn; R. Gossrau, Berlin; W. Graumann, Tübingen; L.-I. Larsson, Copenhagen; Z. Lojda, Prague; B. Maurer-Schultze, Würzburg; A.E.F.H. Meijer, Amsterdam; K. Ogawa, Kyoto; A.G.E. Pearse, London; D. Pette, Konstanz; M. van der Ploog, Leiden; H. Puchtler, Augusta, GA; Y. Sano, Kyoto; and L.A. Sternberger, Rochester, NY. Last year, we celebrated the 60th anniversary of the founding of the journal, exemplifying its longevity in a crowded and expanding scientific publishing marketplace. This gave us pause to reflect on the history of the journal, and what it means as an author today to contribute a manuscript to a journal with such a robust scientific pedigree. In 2008, on the occasion of its 50th anniversary, Jürgen Roth, H. Dariush Fahimi, and Detlev Drenckhahn presented an historical overview of the evolution of Histochemistry and Cell Biology (Roth et al. 2008) since its inception in 1958 as the "Abteilung Histochemie" (Histochemistry Division) of the "Zeitschrift für Zellforschung und mikroskopische Anatomie" (nowadays Cell and Tissue Research). Over the ensuing 60 years, the journal's name has changed three times, reflecting overall movement in the field and scientific literature in general: (1) in 1964-1965, the journal established itself as an independent entity with concomitant change of name to Histochemie/Histochemistry/Histochimie, the three languages reflecting its broad international reach and appeal; (2) in 1974, reflecting the ubiquitous nature of the English language in scientific publications, including those submitted to this journal, the name was changed to Histochemistry; and (3) finally, in 1995 under the leadership of Co-Editors-in-Chief Detlev Drenckhahn and Jürgen Roth, the current name Histochemistry and Cell Biology was adopted, recognizing the expanding scope of articles to be more inclusive of the rapid advances in basic cell and molecular research (Fig. 1). As Juliet famously remarked in Shakespeare's play "Romeo and Juliet", "What's in a name? That which we call a rose by any other name would smell as sweet", may be an apt metaphor for the change in the name of our journal over the past 60 years. And, though the name 

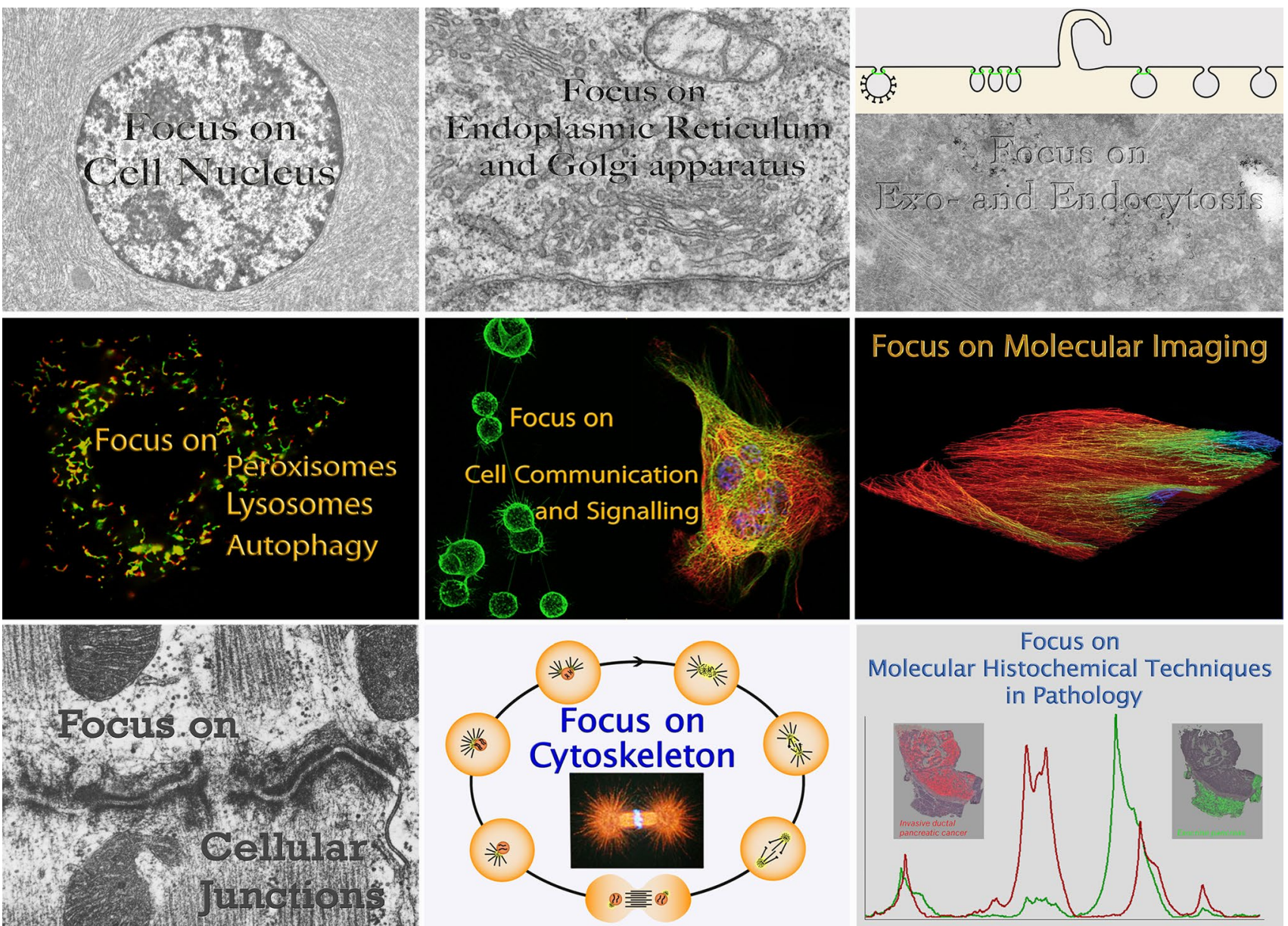

Focus on

Molecular Histochemical Techniques in Pathology
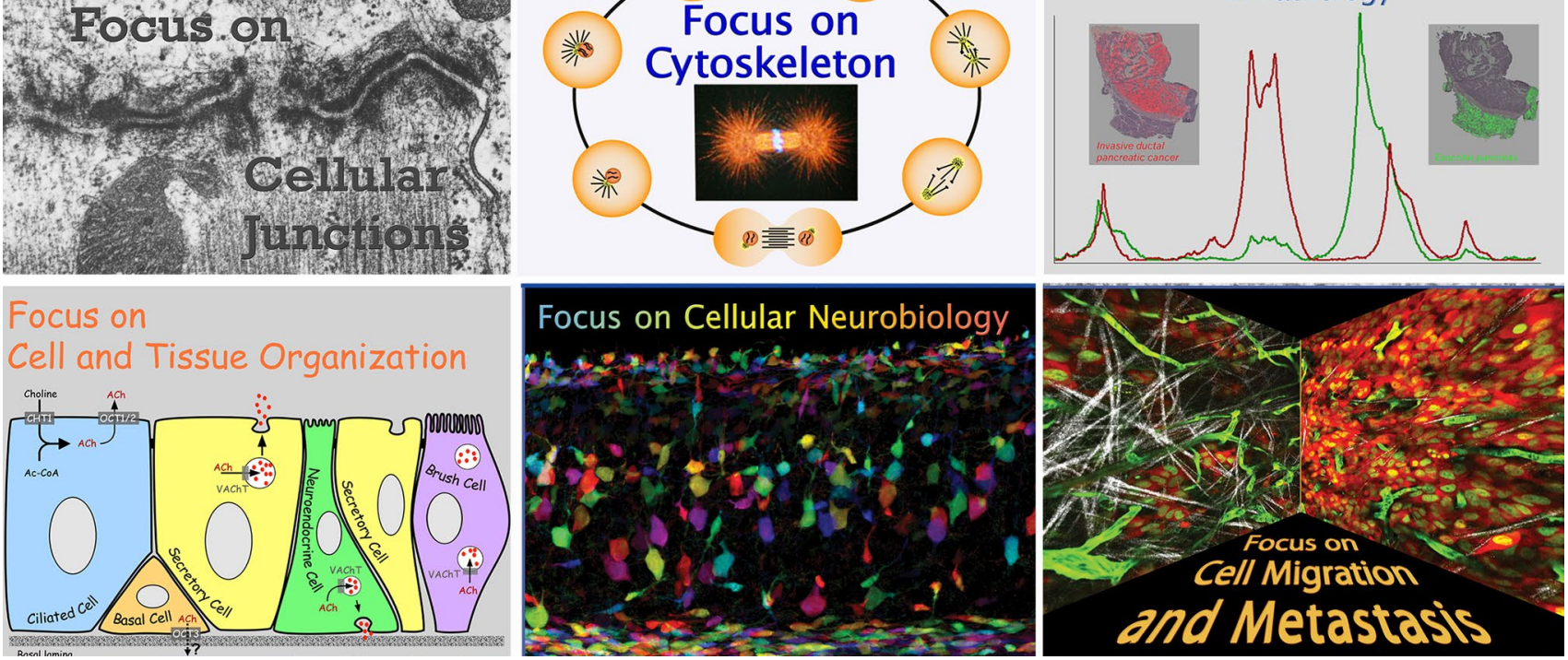

Fig. 1 The collage shows the cover pictures of the 12 issues of Histochemistry and Cell Biology published on the occasion of the journal's 50th anniversary in 2008. They illustrate the long and distinguished history of the journal in publishing histochemical methods in the

may have changed to reflect the growth and maturation of both scientific publishing practices, as well as the science itself, the underlying objectives to publish high-quality manuscripts illustrating technical innovations in histochemistry and their application in original research in cell and molecular sciences have remained steadfast guiding principles. broadest sense, together with molecular imaging techniques for the localization, identification and characterization of cellular and extracellular components as well as metabolic activities under physiological and pathological conditions

\section{Official journal of the Society for Histochemistry}

In 1992, while the journal was still called Histochemistry, Jürgen Roth, as Co-Editor-in-Chief, oversaw the process whereby Histochemistry was adopted as the official journal 
of the Society for Histochemistry (see Gössner 2002, for a brilliant descriptive history of the Society for Histochemistry). The journal provides a forum for the wide dissemination of information regarding activities of the Society (Höfler and Drukker 1992), including the invitation for scientists to apply for the Robert Feulgen Prize. This strong affiliation between journal and Society remains in place to this day. One of the more tangible results of this affiliation has been the publication of the Society's "Robert Feulgen Lecture". This prestigious international invited lecture honoring Robert Feulgen, the pioneer of DNA histochemistry (Chieco and Derenzini 1999), was first delivered by Olavi Eränkö in 1979, who was followed over the years by numerous notable and internationally recognized scientists (Table 1). In addition to the manuscripts from the Robert Feulgen Lecturers, special individual reviews from the Robert Feulgen Prize recipients have also been published in the journal (Table 2; for a complete list see http://www.histochemistry.eu). Moreover, since 2004, five eminent scientists have been selected to present the Histochemistry and Cell Biology Lecture at either the Annual Symposium of the Society for Histochemistry, or at the International Congress of Histochemistry and Cytochemistry (Table 3), with their presentations likewise published by the journal.

\section{Journal statistics and benefits for the authors}

In addition to publishing special individual manuscripts such as those arising from the Robert Feulgen lectures and Prize presentations, the journal also continues to publish thematic "Special Issues" devoted to a specific technique or well-timed research topics (Table 4 and cover of this issue).

Looking over the last 10 years of the journal, it has been illuminating and gratifying to realize that for manuscripts published between 2008 (the 50th anniversary of the founding of the journal) and 2018 (the 60th anniversary) in Histochemistry and Cell Biology, at least 228 have been downloaded over 1000 times from the journal's website. This includes the classical review on human keratins by Roland
Moll's group, with more than 8500 downloads and 571 cites (Moll et al. 2008), a review on single-molecule localization microscopy by Markus Sauer's group (Klein et al. 2014) with more than 4300 downloads and 66 cites, and an introduction to the sugar code by Hans-Joachim Gabius and Jürgen Roth (2017) with about 4100 downloads and 36 cites, as of this writing! For the interested reader, Table 5 provides a more complete list.

Histochemistry and Cell Biology has also been at the forefront of innovations for scientific publishing and author services. In 1995, concomitant with its change of name to the current Histochemistry and Cell Biology, the journal announced publishing policies stipulating that (1) manuscripts will be published in full format without arbitrary page limits, and (2) no charge for the first color plate (Drenckhahn and Roth 1995). These policies were expanded in 2001 to include no charges for any color reproduction in all manuscripts. In 2000, the journal Editors announced a new service for authors called "Online First", whereby accepted manuscripts were immediately posted online following receipt of the corrected proofs (Editors 2000). This process resulted in a significant decrease in publication time, with the online posting as the official date of publication, along with an assigned unique "Digital Object Identifier" (DOI) which can then be used to access and cite the manuscript. Another feature for authors introduced by the publisher in 2004 was the option of "Springer Open Choice", allowing immediate free access to the published articles. More recently, the "Transfer Desk" option was introduced to assist authors in finding the most relevant journal amongst Springer Nature's portfolio of over 2500 titles, for disposition of a manuscript determined by the editors to be beyond the scope of Histochemistry and Cell Biology.

Therefore, in closing, we cordially invite you to submit your manuscripts to Histochemistry and Cell Biology, rich in the knowledge that you will be contributing to a journal with a long-standing history and august reputation in the field. 
Table 1 Scientists invited for the Robert Feulgen Lecture

O. Eränkö, Helsinki, Finland

Histochemical observations on the distribution of catecholamines and catecholamine-synthesizing enzymes in the nerve cells and SIF cells of the sympathetic ganglion. Delivered in Gargellen, Austria, 1979

L.A. Sternberger, Rochester, NY, USA

Immunocytochemistry—-past, present, future. Delivered in Würzburg, Germany, 1980

G. Pfefferkorn, Münster, Germany

Histochemische Analyse mit Licht - und Elektronenstrahlen (Histochemical analysis by light and electron microscopy). Delivered in Münster, Germany, 1981

W.E. Stumpf, Chapel Hill, NC, USA

Histochemical characteristics and significance of cell receptors in biology and pathology. Delivered in Gargellen, Austria, 1982

A.G.E. Pearse, London, UK

The phylogeny of the diffuse neuroendocrine system. Delivered in Gargellen, Austria, 1983

I.B. Black, New York, NY, USA

Phenotypic plasticity in the nervous system. Delivered in Maastricht, The Netherlands, 1984

K. Weber, Göttingen, Germany

Cytoskeletal proteins: structure, function, pathology. Delivered in Göttingen, Germany, 1985

G.C. Bennett, Montreal, Canada

Radioautographic and cytochemical studies of the synthesis and intracellular transport of glycoproteins. Delivered in Gargellen, Austria, 1986

W.J. Gehring, Basel, Switzerland

The generation of the body plan as studied by in situ hybridization in the developing embryo. Delivered in Basel, Switzerland, 1987

L.-I. Larsson, Copenhagen, Denmark

Cytochemical detection of regulatory peptides and of mRNA molecules coding for peptide precursors. Delivered in Gargellen, Austria, 1988

W.W. Franke, Heidelberg, Germany

The intermediate filament cytoskeleton and its association with other structures. Delivered in Gargellen, Austria, 1989

M.N. Moore, Plymouth, UK

Environmental distress signals: cellular reactions to marine pollution. Delivered in Gargellen, Austria, 1990

J.E. Dumont, Brussels, Belgium

The surface receptors in the model of the thyroid cell. Delivered in Ghent, Belgium, 1991

G. Klein, Stockholm, Sweden

The contribution of oncogenes and tumor suppressor genes to the multistep development of cancer. Delivered in Munich, Germany, 1992

S. Rosen, San Francisco, CA, USA

L-selectin and its endogenous ligands. Delivered in Gargellen, Austria, 1993

M.J. Karnovsky, Boston, MA, USA

Cytochemistry and oxy radicals. Delivered in Heidelberg, Germany, 1994

D. Shotton, Oxford, UK

Electronic light microscopy: Past, present, future. Delivered in Rigi-Kaltbad, Switzerland, 1995

M. Trendelenburg, Heidelberg, Germany

Novel insights into the nucleolar structural complexity and function. Delivered in Gargellen, Austria, 1996

K. Simons, Heidelberg, Germany

Biogenesis of a polarized cell surface in epithelial cells. Delivered in Jena, Germany, 1997

D. Vestweber, Münster, Germany

Molecular mechanisms that control leukocyte extravasation. Delivered in Giessen, Germany, 1998

A. Willie, Cambridge, UK

Apoptosis in the genesis and treatment of cancer. Delivered in Gargellen, Austria, 1999

Jennifer Lippincott-Schwartz, Bethesda, MD, USA

Cell cycle maintenance and biogenesis of the Golgi complex. Delivered in Les Diablerets, Switzerland, 2000

R.G.W. Anderson, Dallas, TX, USA

Caveolae spatially organize signal transduction at the cell surface. Delivered in Vienna, Austria, 2001

T. Misteli, Bethesda, MD, USA

New views of the cell: Genomics, proteomics and dynamic networks. Delivered in Vlissingen, The Netherlands, 2002

A. Engel, Basel, Switzerland

Structure and function of membrane channels. Delivered in Les Diablerets, Switzerland, 2003 
Table 1 (continued)

S. Fakan, Lausanne, Switzerland

The functional architecture of the nucleus as analyzed by ultrastructural cytochemistry. Delivered in Prague, Czech Republic, 2004

M. Dahan, Paris, France

From analog to digital: exploring cell dynamics with single quantum dots. Delivered in Noordwijkerhout, The Netherlands, 2005

Danièle Hernandez-Verdun, Paris, France

The nucleolus: a model for the organization of nuclear functions. Delivered in Stresa, Lake Maggiore, Italy, 2006

M. Frotscher, Freiburg, Germany

New ways of looking at synapses. Delivered in Freiburg i.Br., Germany, 2007

K. Takata, Maebashi, Japan

Localization and trafficking of aquaporin 2 in the kidney. Delivered in Interlaken, Switzerland, 2008

P.J. Peters, Amsterdam, The Netherlands

Cellular organelles as nanomachines. Delivered in Fulpmes, Austria, 2009

S.W. Hell, Göttingen, Germany

Super resolution microscopy. Delivered in Prague, Czech Republic, 2010

R.M. Caprioli, Nashville, TN, USA

Molecular imaging of tissue sections by mass spectrometry: Providing information beyond the microscope. Delivered in Munich, Germany, 2011

Marianne Bronner, Pasadena, CA, USA

Regulatory analysis and imaging of neural crest formation and migration. Delivered in Vienna, Austria, 2012

R.D. Goldman, Chicago, IL, USA

Intermediate filaments: Rare diseases provide insights into their cytoskeletal and nucleoskeletal functions. Delivered in Prague, Czech Republic, 2013

R. Heeren, Amsterdam, The Netherlands

Molecular scales: Imaging signals of disease with mass spectrometry. Delivered in Prague, Czech Republic, 2014

Wendy Bickmore, Edinburgh, UK

Transcription, chromatin structure and nuclear organisation: cause and consequence. Delivered in Vienna, Austria, 2015

T. Alexandrov, Heidelberg, Germany

Metabolite imaging enabled by mass spectrometry and big data analytics. Delivered in Prague, Czech Republic, 2017

C. Cremer, Mainz, Germany

Nuclear genome nanostructure imaging at single molecule resolution. Delivered in Prague, Czech Republic, 2018

This is an updated list based on Gössner (2002) 
Table 2 Reviews published by Robert Feulgen Prize recipients

C.R. Green, N.J. Severs, London, UK

Distribution and role of gap junctions in normal myocardium and human ischaemic heart disease. (Green and Severs 1993)

J.L. Carpentier, Geneva, Switzerland

The journey of the insulin receptor into the cell: from cellular biology to pathophysiology. (Carpentier 1993)

J. Oberdick, Columbus, OH, USA

Evidence for a genetically encoded map of functional development in the cerebellum. (Oberdick 1994)

M. Thiry, Liège, Belgium

New approaches to in situ detection of nucleic acids. (Thiry 1995)

R.W. Dirks, Leiden, The Netherlands

RNA molecules lighting up under the microscope. (Dirks 1996)

Eveline Baumgart, Heidelberg, Germany

Application of in situ hybridization, cytochemical and immunocytochemical techniques for the investigation of peroxisomes. A review including novel data. (Baumgart 1997)

E.J. Speel, Zürich, Switzerland

Detection and amplification systems for sensitive, multiple-target DNA and RNA in situ hybridization: looking inside cells with a spectrum of colors. (Speel 1999)

K. König, Jena, Germany

Laser tweezers and multiphoton microscopes in life sciences. (König 2000)

Jennifer Lippincott-Schwartz, Bethesda, MD, USA

The secretory membrane system studied in real-time. (Lippincott-Schwartz 2001)

J. Priller, Berlin, Germany

Grenzgänger: adult bone marrow cells populate the brain. (Priller 2003)

T. Misgeld, Cambridge, MA, USA

Death of an axon: studying axon loss in development and disease. (Misgeld 2005)

M. Nilsson, Uppsala, Sweden

Lock and roll: single-molecule genotyping in situ using padlock probes and rolling-circle amplification. (Nilsson 2006)

Ana Pombo, London, UK

Advances in imaging the interphase nucleus using thin cryosections. (Pombo 2007)

B.M. Giepmans, Groningen, The Netherlands

Bridging fluorescence microscopy and electron microscopy. (Giepmans 2008)

P.F. Lenne, Marseille, France

Probing cell-surface dynamics and mechanics at different scales. (Lenne 2009)

Heidi de Wit, Amsterdam, The Netherlands

Morphological docking of secretory vesicles. (de Wit 2010)

A. Römmp, Giessen, Germany

Mass spectrometry imaging with high resolution in mass and space. (Römpp and Spengler 2013)

Y. Shav-Tal, Ramat Gan, Israel

Zooming in on single active genes in living mammalian cells. (Yunger et al. 2013)

T. Misteli, Bethesda, MD, USA

Deep imaging: the next frontier in microscopy. (Roukos and Misteli 2014)

H. Kimura, Yokohama, Japan

Visualizing posttranslational and epigenetic modifications of endogenous proteins in vivo. (Kimura et al. 2015) 
Table 3 Scientists selected for the Histochemistry and Cell Biology Lecture

P. Friedl, University of Würzburg, Germany

Dynamic Imaging of Cellular Interactions with Extracellular Matrix

Delivered at the 12th International Congress of Histochemistry and Cytochemistry, La Jolla, CA, USA, 2004

(Friedl 2004)

W. Baumeister, Max Planck Institute for Biochemistry, Martinsried, Germany

Cryo-Electron Tomography of Cells: Connecting Structure and Function

Delivered at the 50th Symposium of the Society for Histochemistry, Interlaken, Switzerland, 2008

(Lucic et al. 2008)

S. Yokota, Nagasaki International University, Nagasaki, Japan

Nuage Proteins: their Localization in Subcellular Structures of Spermatogenic Cells as Revealed by Immunoelectron Microscopy

Delivered at the 14th International Congress of Histochemistry and Cytochemistry, Kyoto, Japan, 2012

(Yokota 2012)

A. Luini, Consiglio Nazionale Delle Ricerche and Telethon Institute for Genetics and Medicine, Naples, Italy

Correlative Video-Light-Electron Microscopy: Development, Impact and Perspectives

Delivered at the 56th Symposium of the Society for Histochemistry, Prague, Czech Republic, 2014

(Rizzo et al. 2014)

M. Sauer, University of Würzburg, Würzburg, Germany

Artifacts in Single-Molecule Localization Microscopy

Delivered at the 57th Symposium of the Society for Histochemistry, Vienna, Austria, 2015

(Burgert et al. 2015) 
Table 4 Special Issues published by Histochemistry and Cell Biology

25 Years of Colloidal Gold Labeling

Editor: J. Roth, Zurich, Switzerland

Volume 106, issue 1, 1996

In Situ Hybridization and Related Techniques

Editors: H. Höfler, Munich, Germany and A.K. Raap, Leiden, The Netherlands

Volume 108, issues 4 and 5, 1997

Centennial of the Golgi Apparatus

Editors: Margit Pavelka, Vienna, Austria and D.J. Morré, West Lafayette, IN, USA

Volume 109, issues 5 and 6, 1998

Histochemistry in Gene Technology

Editors: F.T. Bosman, Lausanne and J. Roth, Zurich, Switzerland

Volume 115, issue 1, 2001

Secretion, Endocytosis, Quality Control

Editors: Margit Pavelka, Vienna, Austria and J. Roth, Zurich, Switzerland

Volume 117, issue 2, 2002

Active Oxygen and Nitrogen Species in Biology

Editors: J.M. Robinson, Columbus, OH, USA, H. Seguchi, Kochi, Japan and J.A. Badwey, Boston, MA, USA

Volume 122, issue 4, 2004

Functional Structure of the Cell Nucleus

Editors: P. Hozák, Prague, Czech Republic and S. Fakan, Lausanne, Switzerland

Volume 125, issues 1 and 2, 2006

In Focus: Intermediate Filaments

Editors: P. Hozák, Prague, Czech Republic, P. Debbage, Innsbruck, Austria and J. Roth, Zurich, Switzerland

Volume 140, issue 1, 2013

In Focus: Golgi Apparatus

Editors: Margit Pavelka, Vienna, Austria and J. Roth, Zurich, Switzerland

Volume 140, issues 3 and 4, 2013

In Focus: Single-Molecule Super-Resolution Microscopy

Editors: M. Heilemann, Frankfurt a.M., Germany and J. Roth, Zurich, Switzerland

Volume 141, issue 6 and volume 142, issue 1, 2014

In Focus: The Cell Nucleus

Editors: Klara Weipoltshammer and Ch. Schöfer, Vienna, Austria

Volume 145, issue 4, 2016

In Focus: From Cell Biology to Tissue Structure and Function

Editor: Esther Asan, Würzburg, Germany

Volume 146, issue 6, 2016

In Focus: The Sugar Code

Editors: H.-J. Gabius, Munich, Germany and J. Roth, Zurich, Switzerland

Volume 147, issue 2, 2017

In Focus: Hard Tissue Biology

Editors N. Amizuka, Sapporo and S. Kitazawa, Toon, Japan

Volume: 149, issue 4, 2018 
Table 5 Article impact assessed as number of pdf downloads and citations $(n)$

$n \quad$ Article

8500/571 Moll et al.: The human keratins: biology and pathology. (Moll et al. 2008)

6600/170 Römpp and Spengler: Mass spectrometry imaging with high resolution in mass and space. (Römpp and Spengler 2013)

5400/233 Lorusso and Rüegg: The tumor microenvironment and its contribution to tumor evolution toward metastasis. (Lorusso and Rüegg 2008)

5100/97 Satir and Christensen: Structure and function of mammalian cilia. (Satir and Christensen 2008)

5000/190 Walch et al.: MALDI imaging mass spectrometry for direct tissue analysis: a new frontier for molecular histology. (Walch et al. 2008)

4900/272 Förster: Tight junctions and the modulation of barrier function in disease. (Förster 2008)

4800/59 Baratta et al.: Cellular organization of normal mouse liver: a histological, quantitative immunocytochemical, and fine structural analysis. (Baratta et al. 2009)

4500/39 Vidak and Foisner: Molecular insights into the premature aging disease progeria. (Vidak and Foisner 2016)

4300/66 Klein et al.: Eight years of single-molecule localization microscopy. (Klein et al. 2014)

4100/36 Gabius and Roth: An introduction to the sugar code. (Gabius and Roth 2017)

4100/197 Zimmermann and Dours-Zimmermann: Extracellular matrix of the central nervous system: from neglect to challenge. (Zimmermann and Dours-Zimmermann 2008)

3900/33 Robertson et al.: Use of labeled tomato lectin for imaging vascular structures. (Robertson et al. 2015)

3800/140 Debbage and Jaschke: Molecular imaging with nanoparticles: giant roles for dwarf actors. (Debbage and Jaschke 2008; Thurner and Debbage 2018)

3200/122 Studer et al.: Electron microscopy of high pressure frozen samples: bridging the gap between cellular ultrastructure and atomic resolution. (Studer et al. 2008)

3100/204 Fujimoto et al.: Lipid droplets: a classical organelle with new outfits. (Fujimoto et al. 2008)

3100/6 Galvagni et al.: An apical actin-rich domain drives the establishment of cell polarity during cell adhesion. (Galvagni et al. 2012)

3100/24 Kolesová et al.: Comparison of different tissue clearing methods and 3D imaging techniques for visualization of GFP-expressing mouse embryos and embryonic hearts. (Kolesová et al. 2016)

3100/42 Ohsaki et al.: A pitfall in using BODIPY dyes to label lipid droplets for fluorescence microscopy. (Ohsaki et al. 2010)

3000/43 Deschout et al.: Progress in quantitative single molecule localization microscopy. (Deschout et al. 2014)

3000/98 Schrader and Fahimi: The peroxisome: still a mysterious organelle. (Schrader and Fahimi 2008; Islinger et al. 2018)

3000/212 Sirri et al.: Nucleolus: the fascinating nuclear body. (Sirri et al. 2008)

2700/45 Castañón et al.: Plectin-intermediate filament partnership in skin, skeletal muscle, and peripheral nerve. (Castañón et al. 2013)

2700/60 Giepmans: Bridging fluorescence microscopy and electron microscopy. (Giepmans 2008)

2700/37 Corfield: Eukaryotic protein glycosylation: a primer for histochemists and cell biologists. (Corfield 2017)

2700/98 Deryugina and Quigley: Chick embryo chorioallantoic membrane model system to study and visualize human tumor cell metastasis. (Deryugina and Quigley 2008)

2700/79 Marks et al.: Use of bodipy-labeled sphingolipid and cholesterol analogs to examine membrane microdomains in cells. (Marks et al. 2008)

2600/68 Endesfelder et al.: A simple method to estimate the average localization precision of a single-molecule localization microscopy experiment. (Endesfelder et al. 2014)

2500/39 Bhide and Colley: Sialylation of N-glycans: mechanism, cellular compartmentalization and function. (Bhide and Colley 2017)

2500/89 Bosma et al.: The lipid droplet coat protein perilipin 5 also localizes to muscle mitochondria. (Bosma et al. 2012)

2500/21 Kimura et al.: Visualizing posttranslational and epigenetic modifications of endogenous proteins in vivo. (Kimura et al. 2015)

$2500 / 101$ Waschke: The desmosome and pemphigus. (Waschke 2008)

2500/28 Yusuf and Brand-Saberi: Myogenesis and muscle regeneration. (Yusuf and Brand-Saberi 2012)

Manuscripts published between 2008 and 2018. Threshold number of pdf downloads $\geq 2500$ as per April 2019

\section{References}

Baratta JL, Ngo A, Lopez B et al (2009) Cellular organization of normal mouse liver: a histological, quantitative immunocytochemical, and fine structural analysis. Histochem Cell Biol 131:713-726. https://doi.org/10.1007/s00418-009-0577-1

Baumgart E (1997) Application of in situ hybridization, cytochemical and immunocytochemical techniques for the investigation of peroxisomes. A review including novel data. Histochem Cell Biol 108:185-210
Bhide GP, Colley KJ (2017) Sialylation of N-glycans: mechanism, cellular compartmentalization and function. Histochem Cell Biol 147:149-174. https://doi.org/10.1007/s00418-016-1520-x

Bosma M, Minnaard R, Sparks LM et al (2012) The lipid droplet coat protein perilipin 5 also localizes to muscle mitochondria. Histochem Cell Biol 137:205-216. https://doi.org/10.1007/s0041 8-011-0888-X

Burgert A, Letschert S, Doose S, Sauer M (2015) Artifacts in singlemolecule localization microscopy. Histochem Cell Biol 144:123132. https://doi.org/10.1007/s00418-015-1340-4 
Carpentier JL (1993) The journey of the insulin receptor into the cell: from cellular biology to pathophysiology. Histochemistry 100:169-184

Castañón MJ, Walko G, Winter L, Wiche G (2013) Plectin-intermediate filament partnership in skin, skeletal muscle, and peripheral nerve. Histochem Cell Biol 140:33-53. https://doi.org/10.1007/ s00418-013-1102-0

Chieco P, Derenzini M (1999) The Feulgen reaction 75 years on. Histochem Cell Biol 111:345-358

Corfield A (2017) Eukaryotic protein glycosylation: a primer for histochemists and cell biologists. Histochem Cell Biol 147:119-147. https://doi.org/10.1007/s00418-016-1526-4

de Wit H (2010) Morphological docking of secretory vesicles. Histochem Cell Biol 134:103-113. https://doi.org/10.1007/s0041 8-010-0719-5

Debbage P, Jaschke W (2008) Molecular imaging with nanoparticles: giant roles for dwarf actors. Histochem Cell Biol 130:845-875. https://doi.org/10.1007/s00418-008-0511-y

Deryugina EI, Quigley JP (2008) Chick embryo chorioallantoic membrane model systems to study and visualize human tumor cell metastasis. Histochem Cell Biol 130:1119-1130. https://doi. org/10.1007/s00418-008-0536-2

Deschout H, Shivandan A, Annibale P et al (2014) Progress in quantitative single-molecule localization microscopy. Histochem Cell Biol 142:5-17. https://doi.org/10.1007/s00418-014-1217-y

Dirks RW (1996) RNA molecules lighting up under the microscope. Histochemistry 106:151-166

Drenckhahn D, Roth J (1995) Histochemistry on the move. Histochemistry $103: 1$

Editors (2000) Histochemistry and Cell Biology announces online first publication. Histochem Cell Biol 113:249. https://doi. org/10.1007/s004180000133

Endesfelder U, Malkusch S, Fricke F, Heilemann M (2014) A simple method to estimate the average localization precision of a singlemolecule localization microscopy experiment. Histochem Cell Biol 141:629-638. https://doi.org/10.1007/s00418-014-1192-3

Förster C (2008) Tight junctions and the modulation of barrier function in disease. Histochem Cell Biol 130:55-70. https://doi. org/10.1007/s00418-008-0424-9

Friedl P (2004) Dynamic imaging of cellular interactions with extracellular matrix. Histochem Cell Biol 122:183-190. https://doi. org/10.1007/s00418-004-0682-0

Fujimoto T, Ohsaki Y, Cheng J, Suzuki M, Shinohara Y (2008) Lipid droplets: a classic organelle with new outfits. Histochem Cell Biol 130:263-279. https://doi.org/10.1007/s00418-008-0449-0

Gabius HJ, Roth J (2017) An introduction to the sugar code. Histochem Cell Biol 147:111-117. https://doi.org/10.1007/s0041 8-016-1521-9

Galvagni F, Baldari CT, Oliviero S, Orlandini M (2012) An apical actin-rich domain drives the establishment of cell polarity during cell adhesion. Histochem Cell Biol 138:419-433. https://doi. org/10.1007/s00418-012-0965-9

Giepmans BN (2008) Bridging fluorescence microscopy and electron microscopy. Histochem Cell Biol 130:211-217. https://doi. org/10.1007/s00418-008-0460-5

Gössner W (2002) A brief history of the Society for Histochemistry: its founders, its mission and the first 50 years. Histochem Cell Biol 118:91-94. https://doi.org/10.1007/s00418-002-0437-8

Green CR, Severs NJ (1993) Distribution and role of gap junctions in normal myocardium and human ischaemic heart disease. Histochemistry 99:105-120

Höfler H, Drukker J (1992) Note from the Society for Histochemistry. Histochemistry 97:2

Islinger M, Voelkl A, Fahimi HD, Schrader M (2018) The peroxisome: an update on mysteries 2.0. Histochem Cell Biol 150:443-471. https://doi.org/10.1007/s00418-018-1722-5
Kimura H, Hayashi-Takanaka Y, Stasevich TJ, Sato Y (2015) Visualizing posttranslational and epigenetic modifications of endogenous proteins in vivo. Histochem Cell Biol 144:101-109. https://doi. org/10.1007/s00418-015-1344-0

Klein T, Proppert S, Sauer M (2014) Eight years of single-molecule localization microscopy. Histochem Cell Biol 141:561-575. https ://doi.org/10.1007/s00418-014-1184-3

Kolesová H, Capek M, Radochova B et al (2016) Comparison of different tissue clearing methods and 3D imaging techniques for visualization of GFP-expressing mouse embryos and embryonic hearts. Histochem Cell Biol 146:141-152. https://doi.org/10.1007/ s00418-016-1441-8

König K (2000) Laser tweezers and multiphoton microscopes in life sciences. Histochem Cell Biol 114:79-92

Lenne PF (2009) Probing cell-surface dynamics and mechanics at different scales. Histochem Cell Biol 132:247-252. https://doi. org/10.1007/s00418-009-0620-2

Lippincott-Schwartz J (2001) The secretory membrane system studied in real-time. Histochem Cell Biol 116:97-107. https://doi. org/10.1007/s004180100296

Lorusso G, Rüegg C (2008) The tumor microenvironment and its contribution to tumor evolution toward metastasis. Histochem Cell Biol 130:1019-1103. https://doi.org/10.1007/s00418-008-0530-8

Lucic V, Leis A, Baumeister W (2008) Cryo-electron tomography of cells: connecting structure and function. Histochem Cell Biol 130:185-196. https://doi.org/10.1007/s00418-008-0459-y

Marks DL, Bittman R, Pagano RE (2008) Use of Bodipy-labeled sphingolipid and cholesterol analogs to examine membrane microdomains in cells. Histochem Cell Biol 130:819-832. https://doi. org/10.1007/s00418-008-0509-5

Misgeld T (2005) Death of an axon: studying axon loss in development and disease. Histochem Cell Biol 124:189-196. https://doi. org/10.1007/s00418-005-0036-6

Moll R, Divo M, Langbein L (2008) The human keratins: biology and pathology. Histochem Cell Biol 129:705-733. https://doi. org/10.1007/s00418-008-0435-6

Nilsson M (2006) Lock and roll: single-molecule genotyping in situ using padlock probes and rolling-circle amplification. Histochem Cell Biol 126:159-164. https://doi.org/10.1007/s0041 8-006-0213-2

Oberdick J (1994) Evidence for a genetically encoded map of functional development in the cerebellum. Histochemistry 102:1-14

Ohsaki Y, Shinohara Y, Suzuki M, Fujimoto T (2010) A pitfall in using BODIPY dyes to label lipid droplets for fluorescence microscopy. Histochem Cell Biol 133:477-480. https://doi.org/10.1007/s0041 8-010-0678-x

Pombo A (2007) Advances in imaging the interphase nucleus using thin cryosections. Histochem Cell Biol 128:97-104. https://doi. org/10.1007/s00418-007-0310-x

Priller J (2003) Grenzgänger: adult bone marrow cells populate the brain. Histochem Cell Biol 120:85-91. https://doi.org/10.1007/ s00418-003-0559-7

Rizzo R, Parashuraman S, Luini A (2014) Correlative video-lightelectron microscopy: development, impact and perspectives. Histochem Cell Biol 142:133-138. https://doi.org/10.1007/s0041 8-014-1249-3

Robertson RT, Levine ST, Haynes SM et al (2015) Use of labeled tomato lectin for imaging vasculature structures. Histochem Cell Biol 143:225-234. https://doi.org/10.1007/s00418-014-1301-3

Römpp A, Spengler B (2013) Mass spectrometry imaging with high resolution in mass and space. Histochem Cell Biol 139:759-783. https://doi.org/10.1007/s00418-013-1097-6

Roth J, Fahimi HD, Drenckhahn D (2008) Celebration of the $50^{\text {th }}$ anniversary of publication of Histochemistry and Cell Biology. Histochem Cell Biol 129:1-3. https://doi.org/10.1007/s0041 8-007-0353-z 
Roukos V, Misteli T (2014) Deep Imaging: the next frontier in microscopy. Histochem Cell Biol 142:125-131. https://doi.org/10.1007/ s00418-014-1239-5

Satir P, Christensen ST (2008) Structure and function of mammalian cilia. Histochem Cell Biol 129:687-693. https://doi.org/10.1007/ s00418-008-0416-9

Schrader M, Fahimi HD (2008) The peroxisome: still a mysterious organelle. Histochem Cell Biol 129:421-440. https://doi. org/10.1007/s00418-008-0396-9

Sirri V, Urcuqui-Inchima S, Roussele P, Hernendez-Verdun D (2008) Nucleolus: the fascinating nuclear body. Histochem Cell Biol 129:13-31. https://doi.org/10.1007/s00418-007-0359

Speel EJ (1999) Detection and amplification systems for sensitive, multiple-target DNA and RNA in situ hybridization: looking inside cells with a spectrum of colors. Histochem Cell Biol 112:89-113

Studer D, Humbel BM, Chiquet M (2008) Electron microscopy of high pressure frozen samples: bridging the gap between cellular ultrastructure and atomic resolution. Histochem Cell Biol 130:877-889. https://doi.org/10.1007/s00418-008-0500-1

Thiry M (1995) New approaches to in situ detection of nucleic acids. Histochem Cell Biol 104:81-95

Thurner GC, Debbage P (2018) Molecular imaging with nanoparticles: the dwarf actors revisited 10 years later. Histochem Cell Biol 150:733-794. https://doi.org/10.1007/s00418-018-1753-y

Vidak S, Foisner R (2016) Molecular insights into the premature aging disease progeria. Histochem Cell Biol 145:401-417. https://doi. org/10.1007/s00418-016-1411-1
Walch A, Rauser S, Deininger SO, Höfler H (2008) MALDI imaging mass spectrometry for direct tissue analysis: a new frontier for molecular histology. Histochem Cell Biol 130:421-434. https:// doi.org/10.1007/s00418-008-0469-9

Waschke J (2008) The desmosome and pemphigus. Histochem Cell Biol 130:21-54. https://doi.org/10.1007/s00418-008-0420-0

Yokota S (2012) Nuage proteins: their localization in subcellular structures of spermatogenic cells as revealed by immunoelectron microscopy. Histochem Cell Biol 138:1-11. https://doi. org/10.1007/s00418-012-0962-z

Yunger S, Kalo A, Kafri P et al (2013) Zooming in on single active genes in living mammalian cells. Histochem Cell Biol 140:71-79. https://doi.org/10.1007/s00418-013-1100-2

Yusuf F, Brand-Saberi B (2012) Myogenesis and muscle regeneration. Histochem Cell Biol 138:187-199. https://doi.org/10.1007/s0041 8-012-0972-x

Zimmermann DR, Dours-Zimmermann MT (2008) Extracellular matrix of the central nervous system: from neglect to challenge. Histochem Cell Biol 130:635-653. https://doi.org/10.1007/s0041 8-008-0485-9

Publisher's Note Springer Nature remains neutral with regard to jurisdictional claims in published maps and institutional affiliations. 